Article

\title{
Sustainable Tourism and Renewable Energy: Binomial for Local Development in Cocachimba, Amazonas, Peru
}

\author{
Fátima Calderón-Vargas ${ }^{1}$, David Asmat-Campos ${ }^{2, *}$ (1) and Anselmo Carretero-Gómez ${ }^{1}$ \\ 1 Departamento de Economía y Empresa, Universidad de Almería, 04120 Almería, Spainor \\ fcv715@inlumine.ual.es (F.C.-V.) \\ 2 Grupo de Investigación en Ciencias Aplicadas y Nuevas Tecnologías, Universidad Privada del Norte (UPN), \\ Trujillo 13007, Peru \\ * Correspondence: david.asmat@upn.edu.pe
}

Received: 19 July 2019; Accepted: 31 August 2019; Published: 6 September 2019

check for updates

\begin{abstract}
This article addresses the relationship between sustainable tourism and the use of renewable energy sources. To this end, we evaluate the spatial-temporal tourist flow evolution as well as the wind/solar energy potential in Cocachimba, which is located in the Amazonas region of Peru. This is a place that has seen a considerable increase in tourist activity in the past decade. This is a result of its rich flora and fauna, but especially because of the presence of the Gocta waterfall, considered the third highest in the world. Currently, business initiatives associated with a variety of touristic services have been started. However, there is still a lack of infrastructure, which negatively impacts the tourists' ability to stay overnight. In order to improve the resident-directed services quality and sustainable tourism, we propose the incorporation of sustainable lodging houses that are based, as previously described, on the usage of clean energy sources, which are harmless to the natural environment. To respond effectively to all this, a methodology based on the use of highly reliable sources and databases, statistical analysis, and highly supported physical calculations was used. The study shows that during the peak season there is insufficient lodging. Furthermore, by incorporating sustainable lodging houses, a reduction in fixed costs for the lodging establishments can be reached. We also found that the solar/wind potential possesses the minimal conditions necessary in order to implement heating systems and sustainable electrification based on conventional systems.
\end{abstract}

Keywords: local development; sustainable innovation; sustainable development; sustainable tourism; tourist economy

\section{Introduction}

Local development, as defined by Carbajal, is a set of economical, social, cultural, political, and territorial processes through which a community-from its own environmental opportunities and potentialities - can achieve a state of wellbeing without exclusion or discrimination and guarantee these conditions for future generations [1]. On the basis of this definition, it is also necessary to take into account human development, which necessitates the creation of an environment in which people can expand their maximum potential and lead productive and creative lives, according to their needs and interests [2].

However, local and human development might represent a risk of disrupting the original features of the community and its people. Therefore, it is important to apply proper management strategies and policies that reinforce, in the same proportion, endogenous development. The latter, according to Vásquez, refers to the development of autonomous character, i.e., self-development, which relies on 
the use of own resources, which might be produced in any locality or territory, as all territories possess this potential [3].

Today, the use of renewable energy sources plays a fundamental role, especially in regards to domestic applications [4-6]. Its widespread use is boosted by the strong economies of the east and Asian countries, where annual growth was $1.34 \%$ compared to the global growth of $0.7 \%$ during 2014 [7]. Several studies report that tourism development is closely associated with an increase in energy demand, which causes an adverse environmental impact over each generated sub-activity [8]. Also, there is evidence supporting that some tourist activities are associated with greenhouse gas emissions [9-13]. On the other hand, there is a lack of studies intending to elucidate the energy demand structure in the tourism sector [14-16].

The tourism industry in countries with high tourist influx take three components of energy demand into account [17-19]. Transportation is dominant, accounting for $94 \%$ of energy use, followed by accommodations at 3.5\%, and energy consumption due to the other activities at $2.5 \%$ [20].

One of the required activities to accomplish local development, considering the endogenous preservation, is sustainable tourism. This considers the current and future economic, social, and environmental impacts that satisfying the needs of visitors, industry, environment, and local communities will have [21]. For instance, the implementation of this activity can consider the use of systems based on renewable energy (solar and wind). Furthermore, previous studies conducted by Huamanbal have addressed sustainable local development by pointing out that some issues should be promoted: (i) the development of science, technology, and innovation in Peru, (ii) preservation of the ecosystem, iii) the continuous improvement of human resources in specific fields, (iv) providing goods and services of quality to the community directly or by technological transference in the productive sector and, (v) participating actively in sustainable and inclusive local and regional development [22]. Currently, there is great government support for the development of projects framed in strategies that promote sustainable development, as it is one of the priority objectives of governments, both local and international.

In an approach at the level of the Peruvian territory, it is necessary to highlight that at present energy access in Peru is a problem, especially for rural populations. Over time, the problem has been addressed through the use of different strategies, but in inefficient ways. In fact, $40.5 \%$ of the rural population still does not have access to electricity [23]. Two and a half million Peruvian homes do not possess modern cooking mechanisms. More than one and a half million of those homes are located in rural regions [24].

This scenario seems to be discouraging due to the inefficient application of laws, national programs, and standards for the use and development of renewable energy; however, renewable energy sources in Peru are vast and diverse, and represent an alternative which is economically competitive, technically viable, socially pertinent, and environmentally efficient, and can help address the challenge of overcoming the levels of energy poverty, especially in Peru's rural areas.

Based on the aforementioned, we are in the context of a locality in Peru which justifies the application of theories of sustainable local development and tourism. We focus on the town of Cocachimba, located in the Amazon region, a place that is home to a great diversity of flora and fauna, in addition to the presence of one of the highest waterfalls in the world, which the inhabitants have not been able to take full advantage of, putting only value on the "Gocta Waterfall" (considered the third highest in the world), which has motivated the increase in the number of domestic and foreign tourists for just over a decade. This is one of the characteristics of Cocachimba, despite being a tourist destination that throughout the years has attracted local and foreign tourists, it has motivated tourists to stay only a few hours, for the visit to the Gocta waterfall, due to the lack of accommodation; thus, they do not have enough time to discover the other natural (nature tourism-adventure) attractions the area has to offer.

These facts motivate the proposal, based on the guidelines of a sustainable tourism development (without altering the surrounding ecosystem) and aimed at improving the population's economy, 
conducting a multidisciplinary investigation, proposing to condition the houses of the residents in places of lodging for tourists, thus offering the opportunity for a longer stay and valuing new activities that Cocachimba's potential offers. However, it is necessary to provide houses with standard conditions without altering the environment (air conditioning and electricity), which is why it is proposed to condition them using renewable energy. Thus, using a descriptive orientation, based on the review of national and supranational research, technical and scientific documents, on-site data collection, and participant observation, the synergies between sustainable tourism and renewable energy as allies which contribute to sustainable local development are analyzed. For this, it has been decided to divide the research into four sections. In the first section, an introduction is made based on concepts that relate to the three study variables, local development, sustainable tourism, and renewable energy. In the second section, a review of the literature in the legal context that supports the immersed activities of the study variables is made. In the third section, mention is made of the methodologies used to validate the objectives qualitatively and quantitatively. The fourth section, on results, explains the contribution of renewable energies to sustainable tourism activities for the benefit of local community development; for this purpose it is subdivided into tourist results, results of the study of the renewable energy potential of the study site, and the proposal of the conditioning of the rural houses of the villager, as a local development initiative.

In this study, we analyze renewable energy potential to serve as an alternative to supply tourist energy demand. For this purpose, we consider local organization, the use of clean technology, and the implementation of low ecological impact lodging establishments, as other authors have previously reported on in other contexts [4,6,25], including topics concerning cost reduction in tourist areas [17-19].

\section{Analysis of the Situation}

As part of the research aimed at the proposal to be carried out in this research work, an exhaustive review of the different laws promulgated by government entities in Peru, global treaties, and international protocols in the framework of sustainable development was carried out, with the objective of safeguarding the principles of local and endogenous development of localities in Peruvian territory. For this purpose, the main laws that are framed in the rural area have been considered, as has Cocachimba.

The Peruvian government has for more than two years abided by the General Law of Peasant Communities, Law $\mathrm{N}^{\circ} 24,656$; promote respect and protection of the uses, customs, and traditions of the community, thus promoting the development of their identity. This law supports the creation and development of community enterprises that generate units of products and services to ensure the welfare of its members and the development of the community as a whole [25]. It is a transversal law, which affects different ministeries, especially those involved in foreign trade and tourism, economics, education, and environment.

To support the application of the law, two entities have been created: The National Institute for the Development of Peasant Communities (INDEC), which is the entity in charge of formulating national policies for the development of communities, planning and programming, at a national level, the activities of integral development, and the FONDEC National Fund for Community Development, provider of financial support for the integral development of the communities. It is very important to enforce this law transversally in the different government ministries, especially those involved in foreign trade and tourism, economy, education, and the environment. On the other hand, local governments are currently trying to address their goals using sustainable approaches, based on the objectives set out in the Rio +20 Summit, drawing from this the national plan of environmental action, where in addition to strengthening the increase in public and private investment under a framework of legal, sustainable, ethical and transparent security, they proposed to "contribute to regional and local development by making sustainable use of natural resources, improving environmental quality, reducing levels of poverty, consolidating environmental governance, and strengthening social inclusion and equity in environmental management" [26]. 
Sustainable tourism activity managed in an appropriate way becomes a strategic ally to preserve the environment, generating economic growth and safeguarding the endogenous customs and traditions. For this, it is important to apply in a strategic way those guidelines stipulated in the General Law of Tourism, Law $\mathrm{N}^{\circ} 29,408$, whose purpose is to promote, encourage, and regulate the sustainable development of tourism. Its application is mandatory in the three levels of government, national, regional, and local, in coordination with the different actors linked to the sector [27]. It also indicates that tourism development must ensure the conservation, recovery, and integration of cultural, natural, and social heritage, as well as the responsible use of tourism resources, aiming to improve the quality of life of local communities by strengthening their social, cultural, environmental, and economic development.

Other documents that help us reinforce the aforementioned guidelines are DS 009-92 ICTI, which bases the importance of ecological tourism in a territory, and the $\mathrm{RM} \mathrm{N}^{\circ}$ 0314-2002-AG complementary provisions ecotourism, among others.

The Brundtland Commission of the United Nations Organization [28] defined sustainable development in 1987 as progress that meets the needs of the present without damaging the ability of future generations to meet their own needs. From that moment, this paradigm has been present; from the Rio Earth Summit in 1992, to the Paris conference in 2015, through the World Summit on Sustainable Development in 2002, and the Earth Summit Rio + 20 in 2012. In these meetings, topics were discussed and they reached agreements to promote, directly or indirectly, sustainable development. Between the Agenda 21 ratified at the Rio summit and the 2030 Agenda adopted by the UN in 2015, there have been events of vital importance, such as the Kyoto Protocol and the Millennium Development Goals, which have had the corresponding impact on documents and regulations at all levels: supranational (EU), national, regional, and local. All this has contributed to raising awareness among more and more people about the importance of sustainable development, although there is still much to be done in the field of events.

Guimaraes argued that we must advocate for a style of development that is environmentally sustainable in the access to and use of natural resources and in the preservation of biodiversity; socially sustainable in reducing poverty and social inequalities to promote justice and fairness; culturally sustainable in the conservation of the system of values, practices, and symbols of identities of different peoples, while promoting interculturality; politically sustainable in promoting democratic practices and ensuring access and participation for all in public decision-making; and finally, economically sustainable, shedding light onto new modes of production and consumption, which at the same time is respectful of ecosystems and the biosphere [29]. Considering the aforementioned, to date, new models of development based on sustainable parameters have been implemented. These were established according to the sustainable development goals and the world charter of sustainable tourism agreed to by the United Nations Environment Programme and the World Tourism Organization.

To achieve this, it is necessary to resort to activities that can be developed in the field of sustainability, which are within the reach of those involved.

In the energy context, world energy demand is mostly satisfied by fossil fuels, which are associated with $\mathrm{CO}_{2}$ production and being responsible for the greenhouse effect. The tourism sector is not far from this fact, since fossil fuels are also used in several activities that harm eco-tourism. According to the WTO, the emission of greenhouse gases in tourism activities is around 5\% [30], from this total, $75 \%$ comes from transport, $21 \%$ from accommodation, and $4 \%$ from other related activities [31].

\section{Methodology}

This study presents first the antecedents of tourist activity in Cocachimba and its impact on the main natural attraction - the Gocta waterfall—which has stimulated the tourist flux and their activities in the area. We also analyzed the lack of touristic services, paying special attention to the lodging services as the main variable of the study. This deficit has a direct economic impact, since the longer the tourists stay in the area, the greater the income for the locals, who can also offer new tourist alternatives. 
Next, the potential for renewable energy potential of the area, solar and wind, was analyzed in order to take advantage of it in the design of bioclimatic houses or ecological shelters with sustainable designs.

Cocachimba, which is geographically located in the eastern Peruvian Andes, is the village chosen for this study. It belongs to the Valera district in the Amazonas region, $1829 \mathrm{~m}$ above sea level, with a pleasant warm and dry climate very typical for high altitude jungle areas. The average temperature fluctuates between 13 and 26 degrees Celsius and the rainy season is from November to April. Cocachimba is located within the tourist area of Chachapoyas, an important tourist destination whose attraction comes from the Fortress of Kuelap, the sarcophagi of Karajia, and the lagoon of the condors; however, the main attraction is the "Gocta" waterfall, considered one of the highest in the world by National Geographic.

The data used in this study were taken from scientific papers (Scopus and Web Of Science) and well-known world organizations: the World Tourism Organization (WTO), which allowed us to have an overview of tourism trends, as well as the importance of sustainable tourism internationally; we also resorted to using data from various United Nations sub-organizations, which helped us to reinforce and sustain our proposal and study, in the environmental, social, and economic fields. Also, information was provided by the National Institute of Statistics and Data Processing of Peru (INEI, from its acronym in Spanish) to know figures both of the minimum vital remuneration in Peru and number of inhabitants according to age and sex; the Peruvian Ministry of Foreign Trade and tourism [32], (MINCETUR for its acronym in Spanish) was used to obtain tourism data in figures, annual and monthly tourist influx, to know the profile of foreign tourists, and tourism investment projects; IPeru provided information and data on tourism in the center of Cocachimba, the number of tourists visiting the Gocta Waterfall, and current state of attractiveness. Concerning the renewable energy potential study, our analysis was based on the available data from National Aeronautics and Space Administration (NASA), and the Geographic Information System (GIS) provided by SOLARGIS from the World Bank and Energy simulation software.

The information obtained from reliable sources supported the content of the present study while allowing for its replication by the scientific community.

The employed methodology was that of a case study based on data recompilation as well as a comparison of facts, which will support the success or failure of the proposal.

\subsection{Multi-Criteria Approach. TEFASAL Analysis:}

As previously mentioned, the multi-criteria approach enabled us to simultaneously evaluate alternatives considered in the study as a function of the degree of success and their established objectives. This was achieved by quantifying a function through a specific weight, and the ordering of the considered options.

The method consisted of the following: "A", the axiomatic set of options to consider:

$$
A=\left\{a_{i} ; i=1 \ldots n\right\}
$$

and " $\mathrm{C}$ ", being the axiomatic set of evaluation criteria:

$$
C=\left\{C_{j} ; j=1 \ldots m\right\} .
$$

Each evaluation criterion possessed a field $V_{j}$ (numeric, i.e., from 0 to 100; ordinals, i.e., first, second, third).

If an application of the set " $\mathrm{A}$ " is done in $\mathrm{V}_{\mathrm{j}}$, it is possible to assign the evaluation $\mathrm{y}_{\mathrm{ij}}$ of the alternative $a_{i}$ to the criteria $c_{j}$, and obtain a matrix with the following form: 


\begin{tabular}{cccc}
\hline & $\boldsymbol{c}_{\mathbf{1}}$ & $\boldsymbol{c}_{j}$ & $\boldsymbol{c}_{\boldsymbol{m}}$ \\
\hline $\boldsymbol{a}_{\mathbf{1}}$ & $y_{11}$ & $y_{1 j}$ & $y_{1 m}$ \\
\hline $\boldsymbol{a}_{j}$ & & & \\
\hline
\end{tabular}

During the process of multi-criteria analysis, four phases can be distinguished: (a) definition of axiomatic set of alternatives, (b) setting of objectives, criteria, and indices, (c) partial evaluation of each alternative as a function of each criterion, (d) adding of the partial evaluations as a function of the previously weighted criteria [33].

In this study, we used seven criteria, which took into consideration the following priorities (through previous analyses that were carried out in situ and based on characteristics that government standards suggest): $(\mathrm{T})=$ Technical,$(\mathrm{E})=$ Economic,$(\mathrm{F})=$ Financial,$(\mathrm{A})=$ Environmental,$(\mathrm{S})=$ Social, $(\mathrm{A})=$ Administrative, and (L) = Legal, which form the abbreviation "TEFASAL", in which the most viable option is assigned for the highest obtained punctuation, (the intensity of the weights were through the Saaty scale). The methodology was validated by CEPAL [34].

In the present work, following the scheme below, two fundamental characteristics were analyzed. (Figure 1)

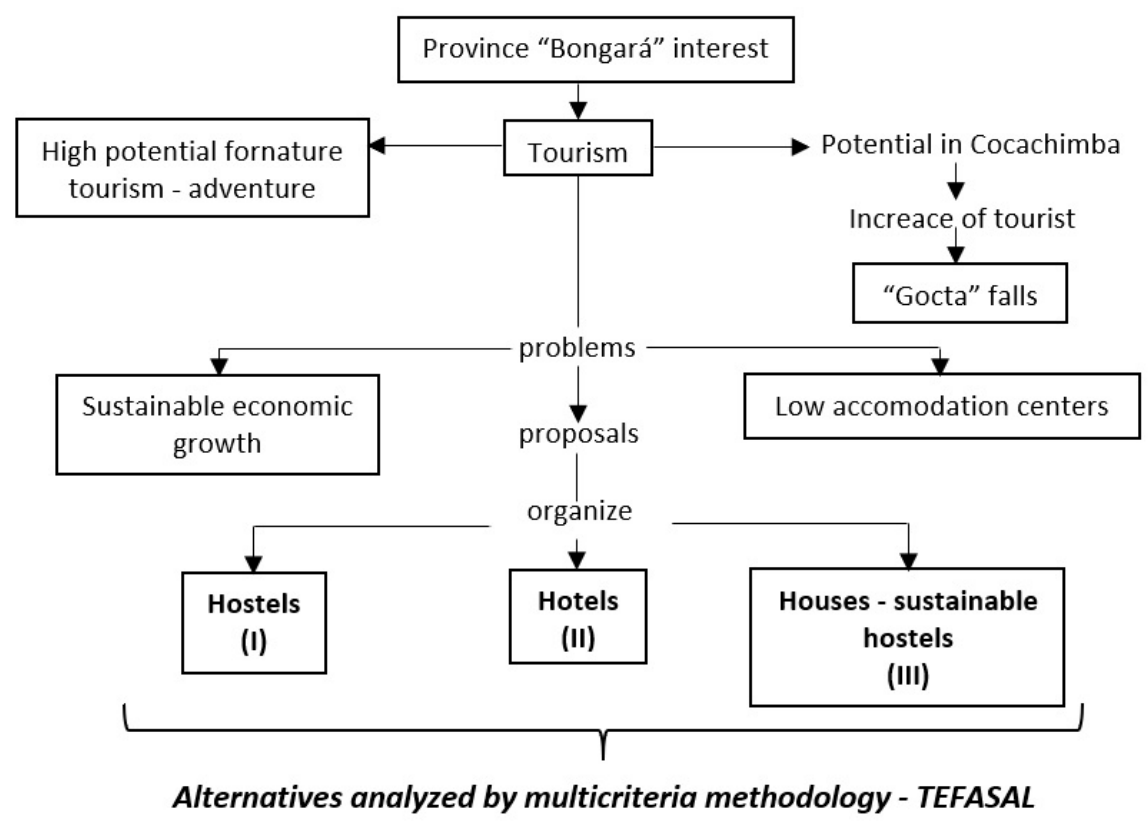

Figure 1. TEFASAL methodology application schema.

\subsection{Sensitivity Analysis Approach}

Sensitivity analysis was the first step taken to identify eventual uncertainties. This was crucial, since we were interested in exploring how the change in one variable might affect the overall result. Additionally, one can identify the most critical variables or build possible scenarios that enable the analysis of the results under different assumptions [17]. In short, the sensitivity analysis allowed us to measure the change in a result, given a change in a set of variables, both in relative and absolute terms. It also improved the quality of the information so that, for instance, an investor possesses additional tools that take into account risks and possible profits to better decide whether or not to invest in a project $[33,35]$.

The importance of this approach relies on the fact that it provides a referential scenario that can be used to compare alternatives based on different energy policy strategies that the government and non-governmental organizations support, in order to improve the economic conditions of various sectors in Peru. Therefore, the model seeks to predict the profitability of housing qualification-sustainable 
shelters, as well as to evaluate the uncertainties related to the model to guarantee its reliability and identify eventual variabilities in the model. To do so, we considered input parameters, some of them quite variable, as the number of tourists staying and costs of preventive-corrective evaluation. We also considered fixed and variable costs of the proposal (previously identified). For the use of this methodology, elements that constituted the adaptation of the houses of the settlers, in sustainable shelters, to the costs demanded by the use of photovoltaic panels, adaptation of the trombe wall, monthly fixed costs, and profits were considered.

\section{Results and Discussion}

The characteristics presented below are the result of extensive research to gather information validated by organizations, such as the National Institute of Statistics and Informatics (INEI-PERU), IPeru, Ministry of Foreign Trade and Tourism (MINCETUR), and especially the work in situ in the study village, for the characteristics of the potential of renewable energies through the study of satellite monitoring, database management, information collection of centers, and face-to-face monitoring, for which all statistical treatment has been given.

\subsection{Tourism in Number: Current Reality in Cocachimba}

The Amazonas region is one of the least inhabited regions and has the fourth lowest population density of all the regions in Peru. Its population in 2015 was estimated to be 422,629 inhabitants [36], representing $1.36 \%$ of the national population. The Amazonas region has seven provinces, one of which is Bongara, which in 2015 had 33,920 inhabitants ( $8 \%$ of the region's population). It possesses twelve districts, including Valera, with 1,281 inhabitants, i.e., $4 \%$ of the province's population. Going from general to particular, we focus now on Cocachimba, where, according to a study conducted by the Amazonas regional government in 2015, only 50 families live, which means between 120 and 300 people. The percentage distribution of the population according to age is shown in the Figure 2.

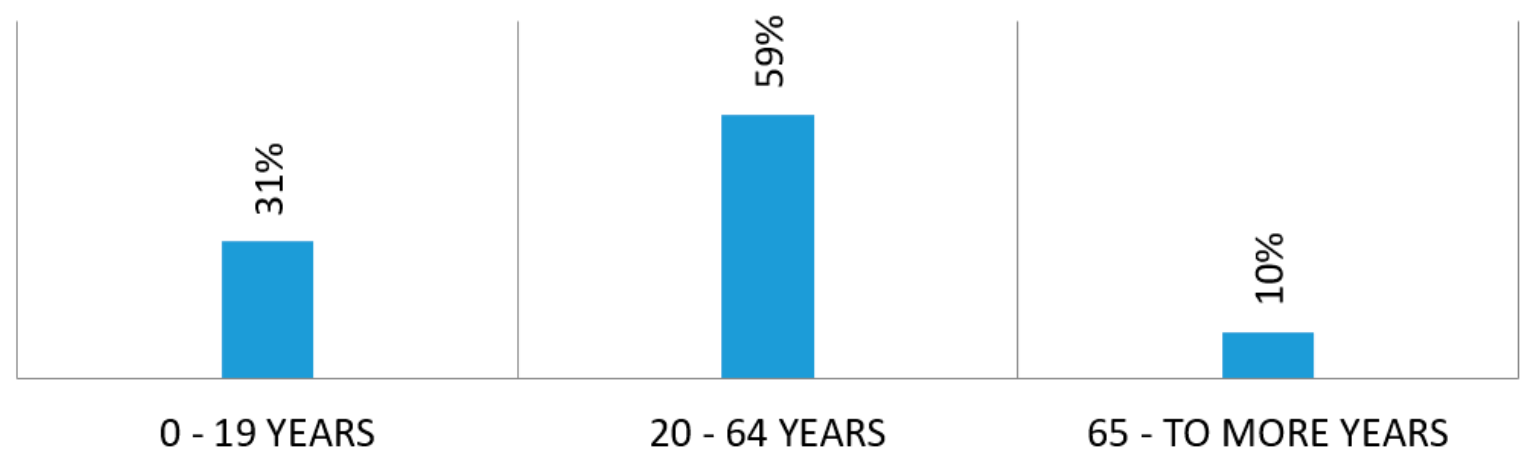

Figure 2. Valera district population in 2015, according to age. Source: Adapted from data of INEI-estimations and projections 2015.

Concerning tourist accommodations, in 2019 there are ten lodging establishments (see Table 1), of which five are not considered formal accommodations since they are small scale family businesses. The other five lodging establishments are classified as lodge, hostel, hotel, and budget hotel, making a total of 122 vacancies for accommodation. These establishments allow for the overnight stay of visitors in the community and generate important income and the possibility of social development for the locals. The Gocta Andes lodge offers a luxury service, personalized treatment, and good location, with rates per night in 2019 ranging from US $\$ 95.00$ to US $\$ 157.00$ per room. The other accommodations are cheaper and belong to local owners. The room rates per night can vary from US\$33.05 to US\$39.89. 
Table 1. Lodging establishments in Cocachimba and their capacities.

\begin{tabular}{ccc}
\hline Classification & Commercial Name & Capacity \\
\hline Lodge & Gocta Andes Lodge & 25 vacancies \\
Lodge & Healthy Stay Gocta & 16 vacancies \\
Guest house & Gocta & 15 vacancies \\
Lodge & Gocta Miradors & 15 vacancies \\
Lodge & Mamaq Tambo Lodge & 15 vacancies \\
Budget Hotel & Gallito de las Rocas & 13 vacancies \\
Lodge & Puente de Gocta & 10 vacancies \\
Lodge & Gocta Lab & 9 vacancies \\
Hostel & Hostel Sachapuyo & 4 vacancies \\
Hostal & La Sirenita de Gocta & - \\
\hline
\end{tabular}

Source: adapted from collected data of IPeru Chachapoyas.

Travel agencies are not available in Cocachimba, although the Gocta lodge indirectly promotes tourism, as it also offers tour packages to its guests. The agencies that advertise Gocta's attractions are located in Chachapoyas. Visitors too contract the services of Lima's agencies, which possess operator partners in other cities, such as Trujillo, Chiclayo, and Cajamarca.

Since 2013, the number of visitors to the Valera district has increased. According to the data taken from the IPeru organization, 16,037 people visited the town in 2013. This number increased to 18,785 in 2014. In 2015 there was a slight reduction (18,467 visitors), which was surprisingly overcome in 2016, when 26,210 visitors were attracted, an increase of $42.5 \%$ with respect to the previous year. Despite the adverse weather events that affected Peru during the first months of 2017 (the "El Niño" phenomenon), the tourist arrival to the Amazonas region is encouraging, since until April 2018, 7917 people visited the Gocta waterfall. This is 230 more visitors than the previous year in the same period of time, suggesting an increase of $41.7 \%$ (Figure 3 ).

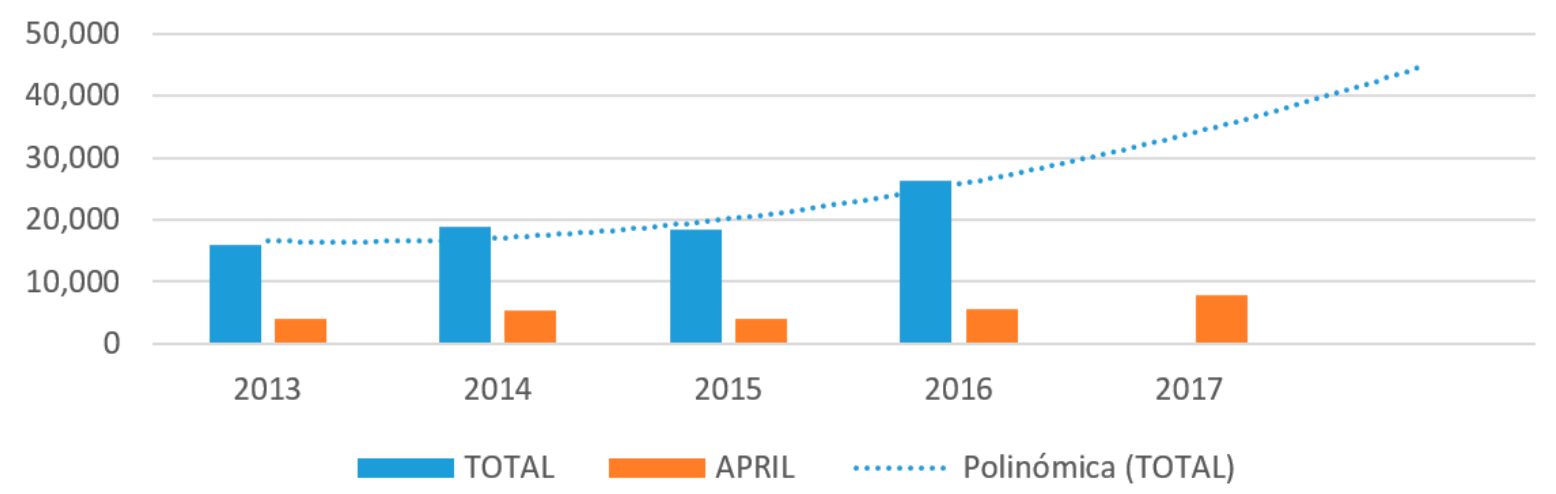

Figure 3. Visitors influx to Gocta waterfall 2013-2016. Source: Adapted from data collected by IPeru Chachapoyas.

Another interesting aspect to analyze is related to the places at which tourists arrive to gain access to the waterfall. Two options are available, as the waterfall splits two communities. First is the San Pablo village, which is the capital of the Valera district and also the closest place to the upper waterfall. The second option is Cocachimba, a smaller village that provides the closest access to the lower waterfall. The data from the last four years show that $80 \%$ of visitors access the waterfall through Cocachimba (Figure 4).

During the months of February to May and December, the Gocta waterfall attracts fewer visitors. This is a consequence of frequent heavy rains, which make it difficult to access the area by automobile. Indeed, the weather conditions are a drawback to visiting this and other tourist attractions, as the majority are found in nature. The off season ranges between 720 to 950 people per month. 


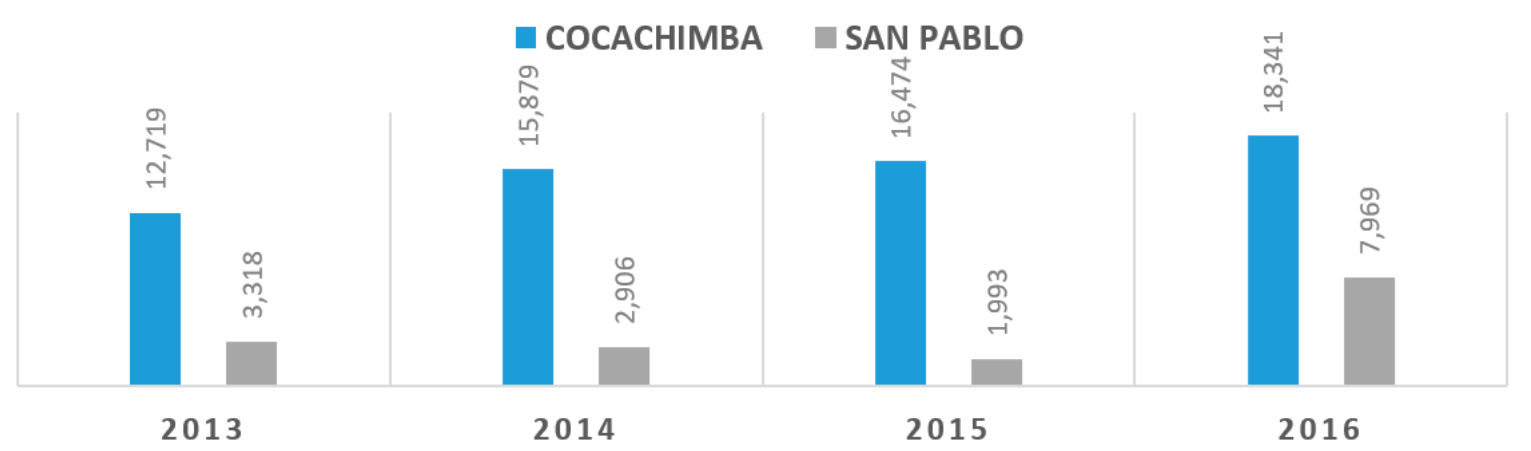

Figure 4. Gocta waterfall visitors according to the village from which they access it. Source: Adapted from collected data of IPeru.

Starting in June, the arrival of tourists begins to pick up pace, with July and August the months with the greatest number of visitors-an average of 2427 per month. These months coincide with the vacation season for Peruvians (due to Independence Day celebrations) and the summer vacations in Europe. Within the three subsequent months, the average number of visitors is approximately 1500 , of which around 1000 to 1250 are Peruvians (See Figure 5).

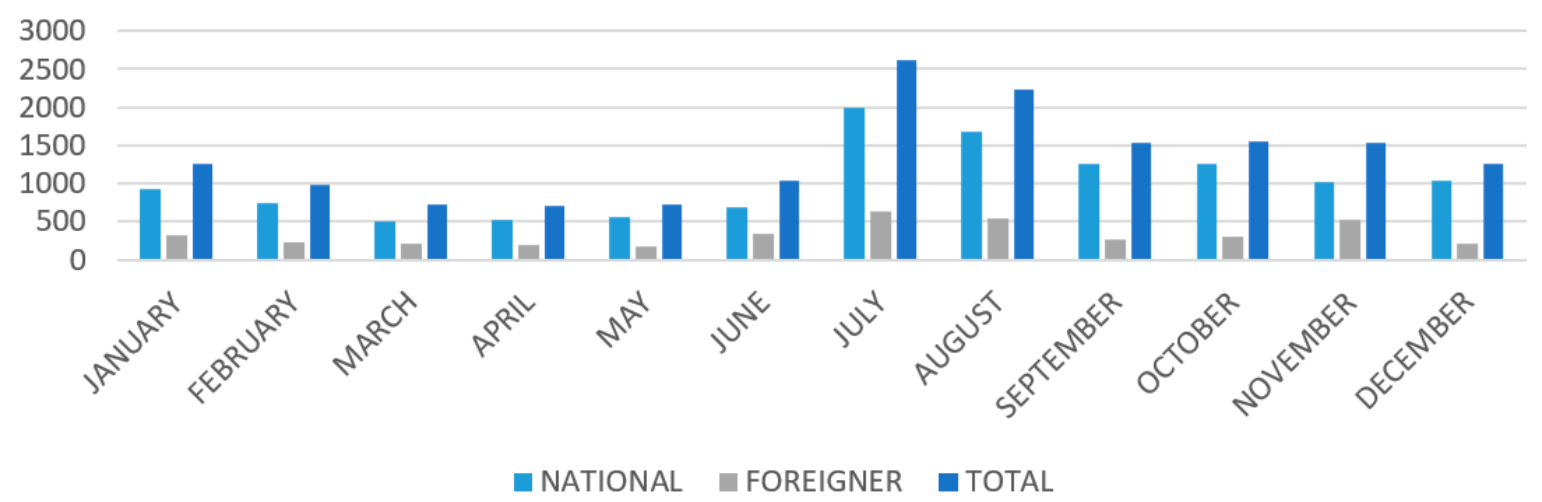

Figure 5. Number of tourists that went to Cocachimba in order to visit Gocta waterfall (by month). Source: Adapted from collected data of IPeru Chachapoyas. The data for each month is computed as the average of the last four years.

Regarding foreign tourism, we noticed that July, August, and November are the months with the highest numbers of visitors. In contrast, the months with the least visitors are April, May, and December.

This information suggests that in 2016, 78\% of visitors were Peruvian. However, as one can notice from Figure 6, the trend for the number of foreign tourists is increasing.

The perspectives for future growth are good, but sustainable management strategies are required, not only for the natural attractions but also for the community (customs, culture). On the other hand, a large portion of the visitors to Cocachimba stay one day, because the lodging establishments are limited (only 122 vacancies are available among the four existing establishments). For instance, in July, considering an average of 2626 visitors, only $61.7 \%$ of tourists found accommodation at their disposal, while $38.3 \%$ could not find available accommodation. This deficit is perhaps the reason why visitors prefer not to stay for long periods of time. 


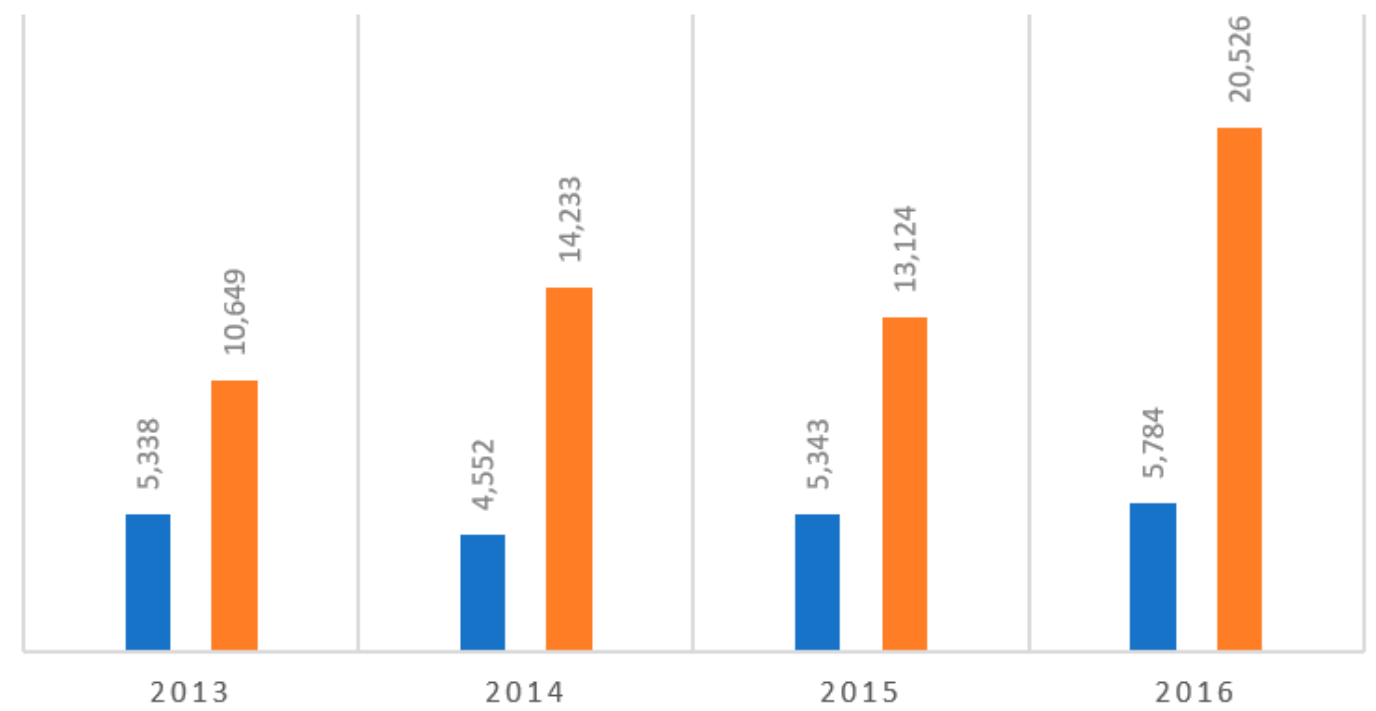

Figure 6. Visitors to the Gocta waterfall according to origin. Source: adapted from collected data of IPeru Chachapoyas.

\subsection{Renewable Energy Potential}

The Peruvian government, through its ministries of energy and mines and the environment, and in turn the legislative power, have highlighted the importance of renewable energy in Peru. For this there are documents (mentioned in this article) which emphasize such issues, and the Peruvian government has created agreements with international entities, such as the Instituto interamericano de cooperación para la agricultura-IICA, and the ACCIONA microenergía Perú-AMP, whose objective is to facilitate access to renewable energy technologies, thermal and electrical [37,38]. In addition, there is cooperation between public universities and the peruvian government; this is how the National University of Engineering, through its Center for Renewable Energies (CER-UNI), has been implementing photovoltaic systems in the tourist area of the communities of the "Uros", "Taquile", "Amantaní" in the Puno region [39].

Consequently, given the support provided by the various governmental and non-governmental entities, it is feasible to generate a proposal that encompasses a projection of social economic development based on sustainability parameters.

For this reason, we focused this research on the locality under study, for this it is crucial to understand the characteristics of the renewable energy potential available in the location. In order to assess this, Geographic Information Systems and Satellite atmosphere data, together with other mechanisms, were used to determine the average solar radiation intensity, i.e., $4.7 \mathrm{kWh} /$ day (see Table 2).

Table 2. Solar radiation intensity in Cocachimba.

\begin{tabular}{cc}
\hline Data & Solar Radiation Intensity (kWh/day) \\
\hline SUD Renewable energy & 4.98 \\
Enair & 4.64 \\
World Bank-SOLARGIS & 4.48 \\
Average & 4.7 \\
\hline
\end{tabular}

Source: Own elaboration based on collected data and simulations SUD renewable energy, EnAir and Solargis.

The used data were taken from the National Aeronautics and Space Administration (NASA), which constitutes maps of 200 satellites over 22 years of stored data of the whole planet. Regarding the 
precision, the estimations of the uncertainty levels for solar radiation, temperature, and wind velocity with respect to data measured on ground are presented.

Our results found end-to-end uncertainties going from 6 to $12 \%$. It is important to consider the uncertainty associated with the measurements, since we dealt with a mesoscale model and a spatial resolution of 0.5 degrees, which could generate a small margin of error.

Nonetheless, based on the experience in this subject matter, we can be certain that we are conducting a reliable study.

After the data processing, we considered the installation of a system based on blended renewable energy sources, such as wind and solar. In Figure 7, we present the schematic representation of the proposed simple blended system.

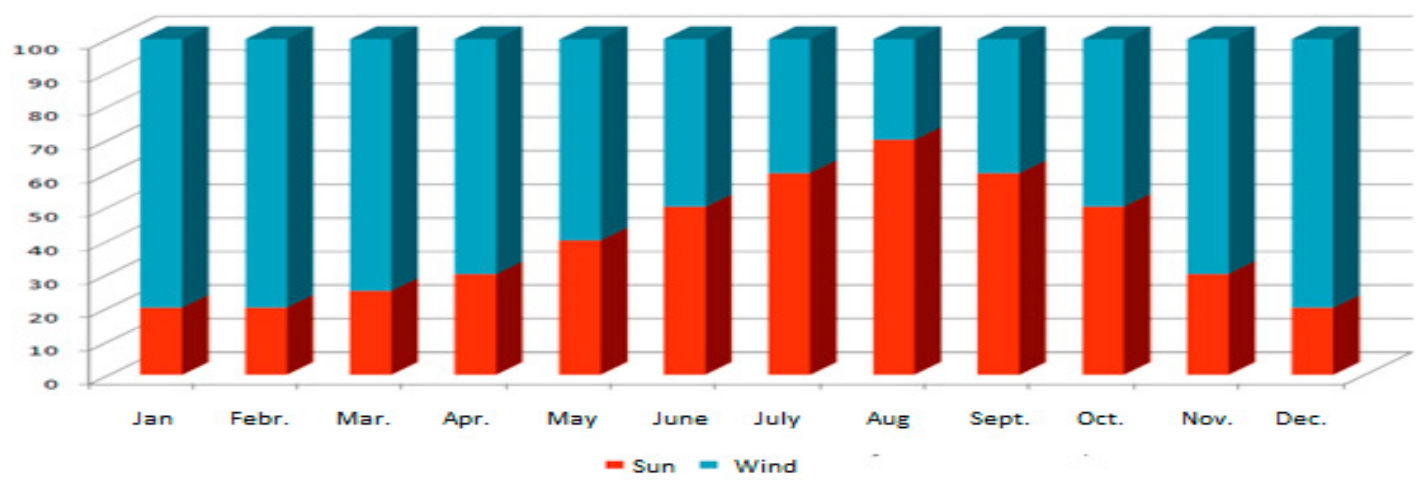

Figure 7. Proposed blended (wind and solar) energy source to be used during a year. Source: EnAir database, 2017.

By combining two natural energy sources (wind and sun), the renewable facilities can become more efficient over the 365 days of the year. Besides this, the generation cycles can be shared between day and night, enabling the generation of energy in uninterrupted cycles of $24 \mathrm{~h}$.

Regularly, during the summer season, the days are sunny with less wind. This suggests that solar panels and other devices with working principles based on the sun are ideal for this season.

During the winter, conditions are windier and less sunny in comparison to summer. This implies that having a wind turbine available would provide precious energy.

Cocachimba is located at the following coordinates: Latitude: $6.0576^{\circ}$ and Longitude: $77.8945^{\circ}$, and an elevation of $1829.4 \mathrm{~m}$ above sea level. Considering its location, we simulated the solar energy potential of the location, which is presented in Table 3.

Table 3. Cocachimba's solar potential obtained by EnAir simulation.

\begin{tabular}{cc}
\hline \multicolumn{2}{c}{ COCACHIMBA's SOLAR POTENTIAL } \\
\hline Solar Energy & $4.64 \mathrm{kWh} /$ day \\
\hline Hours of sun per day & 4.64 \\
Hours of sun per month & 141.23 \\
Hours of sun per year & 1694.71 \\
\hline
\end{tabular}

Source: EnAir data base, 2017.

Similarly, we analyzed the average annual solar potential of the location by using the data GIS-SOLARGIS, which are presented in Table 4. 
Table 4. Annual average of the solar potential in Cocachimba, obtained by SOLARGIS simulations.

\begin{tabular}{cc}
\hline Solar Resource and Air Temperature: & Annual Average \\
\hline Annual horizontal irradiation & $1638 \mathrm{kWh} / \mathrm{m}^{2}$ \\
Direct normal irradiation & $1048 \mathrm{kWh} / \mathrm{m}^{2}$ \\
Diffuse horizontal irradiation & $851 \mathrm{kWh} / \mathrm{m}^{2}$ \\
Global tilted irradiation & $1652 \mathrm{kWh} / \mathrm{m}^{2}$ \\
Air temperature & $14.6{ }^{\circ} \mathrm{C}$ \\
\hline
\end{tabular}

Source: Data base SOLARGIS simulation. World Bank, 2017.

Nonetheless, through the simulation of SUD Energies Renovables, we obtained an annual average with a variation of $9.5 \%$ with respect to the other results (See Table 5).

Table 5. Annual average and daily solar energy of Cocachimba, according to SUD Energies.

\begin{tabular}{cc}
\hline Annual Solar Energy & $1795 \mathrm{kWh} /$ year \\
\hline Daily Solar Energy & $4.98 \mathrm{kWh} /$ day \\
\cline { 2 - 2 } Source: Data base of simulated SUD Energies renovables, 2017.
\end{tabular}

The wind potential in the location was also analyzed by means of the GIS tool of EnAir, getting the results that are summarized in Table 6.

Table 6. Wind potential of Cocachimba obtained by EnAir simulation.

\begin{tabular}{cc}
\hline \multicolumn{2}{c}{ Cocachimba's Wind Potential } \\
\hline Wind Energy & $2.62 \mathrm{kWh} /$ day \\
Average output power & $109.05 \mathrm{~W}$ \\
Annual Energy & $955.29 \mathrm{kWh}$ \\
Monthly Energy & $79.61 \mathrm{kWh}$ \\
Operational time percentage & $62 \%$ \\
Average wind velocity & $2.8 \mathrm{~m} / \mathrm{s}$ \\
\hline Source: EnAir data base, 2017.
\end{tabular}

\subsection{Evaluation of the Proposal for Sustainable Local Tourism Development in Cocachimba}

In light of this, we propose a set of strategies to increase the tourist activities in Cocachimba, so that visitors can stay at least two nights, which would exploit the location's maximum touristic potential.

In addition, the deficit regarding the availability of lodging is a drawback which prevents tourists from staying for longer periods of time. In order to address this issue, we propose the implementation of micro and small business initiatives, (Mypes, for its acronym in Spanish) supervised by locals, that can generate employment and income for the local population and, at the same time, preserve the environment and its customs.

However, given the difficulty in setting a priori the limits to avoid the proposed activity being unsustainable, it is proposed that the process in its first phase be carried out in a "very prudent" manner, so that the vital biophysical parameters of the area are not altered negatively, considering the principles of zero irreversibility, sustainable harvesting, sustainable emptying, sustainable emission, and sustained selection of technology.

For this, three proposals (I, II, and III) were analyzed with the objective of considering only one alternative, this will be dependant on the result that implies the application of the multicriteria methodology. For this purpose the following TEFASAL criteria were defined: Technical ( $T$, represents the level of technical knowledge of the inhabitants, to carry out the alternatives), Economic (E, represents the viability of the budget), Financial (F, represents the facility at the level of loans and economic support to achieve some of the alternatives), Environmental (A, represents the impact on the environment), Social (represents how the customs of the affected social group will be affected), Administrative 
(A, represents local facilities in terms of procedures), and Legal ( $\mathrm{L}$, represents the current state of local and national laws and regulations that promote the proposal).

To build the matrices for the choice of the alternative we relied on the table of Saaty comparison scales (Table 7).

Table 7. Saaty comparison scales.

\begin{tabular}{|c|c|c|}
\hline Escale & Definition & Explanation \\
\hline 1 & Equally preferred & The two criteria contribute equally to the objective. \\
\hline 3 & Moderately preferred & $\begin{array}{l}\text { Experience and judgment favor one criterion a little over } \\
\text { the other. }\end{array}$ \\
\hline 5 & Strongly preferred & $\begin{array}{l}\text { Experience and judgment strongly favor one criterion over } \\
\text { the other. }\end{array}$ \\
\hline 7 & Very strongly preferred & One criterion is favored very strongly over the other. \\
\hline 9 & Extremely preferred & $\begin{array}{l}\text { The evidence favors in the highest measure one factor over } \\
\text { the other. }\end{array}$ \\
\hline $2,4,6,8$ & $\begin{array}{l}\text { Doubt between the } \\
\text { previous values }\end{array}$ & $\begin{array}{l}\text { The preference between the factors cannot be } \\
\text { clearly defined. }\end{array}$ \\
\hline
\end{tabular}

Source: Saaty, 1994 [40].

Following this scale, we made the analysis in pairs to establish the priorities and the weighting of each requirement (Table 8). A value 5 in a cell assumes that the requirement that appears in the row of that value is strongly preferred to that of the column. Thus, for example, the environmental requirement is strongly preferred to the technician, and conversely, when comparing the technical requirement with the environmental one, the value is $1 / 5$.

Table 8. Priority setting and weight calculation.

\begin{tabular}{cccccccccc}
\hline & \multicolumn{10}{c}{ Saaty Scale } \\
\hline Technical Preference & T & E & F & A & S & A & L & Sum & Weighing \\
\hline T & 1 & $1 / 4$ & 2 & $1 / 5$ & $1 / 4$ & 3 & 1 & 7.7 & 9.8 \\
\hline E & 4 & 1 & 3 & $1 / 3$ & $1 / 3$ & 4 & 1 & 13.7 & 17.4 \\
\hline F & $1 / 2$ & $1 / 3$ & 1 & $1 / 4$ & $1 / 2$ & 2 & $1 / 5$ & 4.8 & 6.1 \\
\hline A & 5 & 3 & 4 & 1 & 3 & 4 & 4 & 24 & 30.5 \\
\hline S & 4 & 3 & 2 & $1 / 3$ & 1 & 4 & 4 & 18.3 & 23.3 \\
\hline A & $1 / 3$ & $1 / 4$ & $1 / 2$ & $1 / 4$ & $1 / 4$ & 1 & 1 & 3.6 & 4.6 \\
\hline L & 1 & 1 & 2 & $1 / 4$ & $1 / 4$ & 1 & 1 & 6.5 & 8.3 \\
\hline
\end{tabular}

We list below the alternatives and the criteria (Table 9), assigning values between 0 and 3 (with the aim of simplifying) depending on the degree of adequacy between them. The values were considered based on the technical criteria of the researchers of this work, based on in situ observations, field research, background, reality of the context, quantifying the degree of adequacy to the following [34]: the value of zero $(0)=$ it is a very complex and/or unfeasible context; $(1)=$ complex/moderately viable; (2) = affordable/viable; (3) = very affordable/strongly viable. This allowed quantification by means of an analysis of the researchers and by unanimous decision, to finally put it into function to the weights provided in Table 8. 
Table 9. Weights for the multi-criteria analysis TEFASAL.

\begin{tabular}{|c|c|c|c|c|c|c|c|c|c|}
\hline \multirow{2}{*}{ ALTERNATIVES } & \multicolumn{7}{|c|}{ CRITERIA } & \multirow{3}{*}{ Weighted Sum } & \multirow{3}{*}{ Final Weighting } \\
\hline & $T$ & E & $F$ & $\mathbf{A}$ & S & $\mathbf{A}$ & $\mathbf{L}$ & & \\
\hline Weighting & 0.098 & 0.174 & 0.061 & 0.305 & 0.233 & 0.046 & 0.083 & & \\
\hline I & 1 & 0 & 1 & 1 & 1 & 1 & 1 & 0.83 & 21.75 \\
\hline II & 0 & 0 & 0 & 1 & 1 & 1 & 1 & 0.67 & 17.56 \\
\hline III & 2 & 2 & 2 & 3 & 2 & 2 & 2 & 2.31 & 60.69 \\
\hline \multicolumn{8}{|c|}{ Sum } & $\Sigma=3.81$ & $100 \%$ \\
\hline
\end{tabular}

The results of the final weight were obtained from the respective percentage calculation of the total weighted weight, for example, for alternative (I): 0.83 is $21.75 \%$ of 3.81 .

Considering the aforementioned parameters, which were based on the characteristics described by the surrounding environment, and the social conditions in Peru, Alternative III was the one that would generate different opportunities for exploitation based on the needs of the town of Cocachimba.

Taking into account the costs and profitability, we can afford to take this alternative as a viable method, since we would amortize the costs, generate less environmental impact, and aim to improve local development.

Depending on the results, the proposal relies on the formation, training, and mindfulness of a number of families to form the "Cocachimba communal association of Tourism". This association would seek to generate entrepreneurship by assigning a conditioned area in their homes, while their customs are preserved. This rural home stay accommodation could offer meals, participation in local daily activities, which let the visitors learn more about their customs, and at the same time, generate extra income for the local inhabitants.

In this way we would not only focus on the implementation of elements that help reduce their cost of living based on the use of renewable energies, but also take advantage of the existing infrastructure contributing to the generation of extra economic income. On the other hand, since their lifestyle is a value which adds to the attractiveness, the inhabitants would continue to cultivate their customs, preserving them and revaluing them.

To obtain a photovoltaic system, families can participate in different programs that the Peruvian government has been promoting, such as the program promoted by the Ministry of Energy and Mines, the "First Auction of electricity supplies with renewable energy resources", as part of the policies of the Peruvian state in the field of rural electrification [41]. With respect to the adaptation of dwellings with a "thrombe wall" solar heating system, nowadays the nongovernmental organization "Practical Solutions" [42] has been collaborating with communities in Peru with the construction of this type of technology, economically solving up to $79.18 \%$ and families with $20.81 \%$ constituted by accessible economic amounts. Likewise, MINCETUR promotes the Turismo Emprende program year after year, which promotes the creation, development, and consolidation of tourism ventures that involve local communities, protected natural areas, and cultural heritage, with the main objective of promoting the local economic development. This program is aimed at entrepreneurs who are directed to develop the tourism sector and who have the need to improve their services or undertake a new tourism business [43].

In the case of families with better economic resources that are dedicated to agriculture and decide to take in parallel the tourist activity, they can apply for agricultural loans through AGROBANCO, an entity of the state that promotes the development of prioritizing the segment of small and medium producers located in rural areas [44].

This strategy would also contribute to the start of the empowerment of women, since in Peru and, on a larger scale, in rural areas, men are responsible for generating income in their homes, and women stay at home to take charge of housework and raising children. A business at home would be the ideal opportunity for women to begin to actively participate and contribute to the improvement of the economy in the family basket. 
However, based on the results obtained by applying the TEFASAL multicriteria methodology, this work was specifically designed to increase the number of lodging vacancies by proposing the upgrading of houses partially or totally conditioned with functional elements based on renewable energy, such as solar heating, solar water heating, and photovoltaic cells. These contribute to the reduction in variable and fixed costs related to business.

The overall results clearly show the deficiency of Cocachimba with respect to lodging facilities, despite the increasing rate of visitors over the years. In fact, nowadays, a high percentage of tourists demand to stay in self-sustaining hotels or eco-lodges, according to the profile of the foreign tourist made by MINCETUR [43]. In this regard, Cocachimba turns out to be a suitable place for these purposes due to its geographical location and minimal renewable energy resources, consisting of $4.7 \mathrm{kWh} /$ day (annual average), which can be exploited. As the amount of available renewable energy is minimal, it is necessary to choose hybrid resources (solar, wind, hydraulic) to easily supply the energy demand of the lodging facilities. As the wind potential is deficient in the location $(2.62 \mathrm{kWh} /$ day $)$, we restricted ourselves to the study of the solar potential.

For the sake of illustration, we analyzed a self-sustaining rural home stay with respect to the existing accommodations in Cocachimba, whose results related to energy demand are presented in Table 10.

Table 10. Basic daily energy demand in Cocachimba's lodging establishments.

\begin{tabular}{cccc}
\hline Elements & Power $(\mathbf{W})$ & Operation Hours & Consumption (kWh) \\
\hline TV & 150 & 5 & 0.75 \\
Lighting 1 & 50 & 4 & 0.2 \\
Lighting 2 & 50 & 4 & 0.2 \\
Computer & 200 & 4 & 0.8 \\
Refrigerator & 175 & 14 & 2.45 \\
Microwaves & 1,000 & 1 & 1 \\
Washing machine & 850 & 2 & 1.7 \\
Total & 2,475 & & 7.1 \\
\hline
\end{tabular}

Source: Own elaboration based on collected data OSINERGMIN.

According to the results, we argued that in order to supply a daily energy of $7.100 \mathrm{Wh}$, electricity should be supplied from photovoltaic panels. In this case, our model considered a practical autonomy of 1.31 days. The practical autonomy consisted of running down $50 \%$ of the photovoltaic system battery, while the theoretical autonomy of 2.62 days considered running down the battery $100 \%$.

Considering the running down calculations together with the selected autonomy, and the location potential, the batteries should have a featured capacity of C100, 388 Ah and correspond to stationary accumulators of high quality to ensure their correct function. In Table 11, the data to supply the demanded energy with photovoltaic panels are summarized.

Table 11. Average electricity supply features for photovoltaic panels in a prototype rural home stay in Cocachimba.

\begin{tabular}{|c|c|}
\hline Generated Energy & $7100 \mathrm{kWh}$ \\
\hline Theoretical Autonomy & 2.62 days \\
\hline Tension & $48 \mathrm{~V}$ \\
\hline Capacity & $388 \mathrm{Ah}$ in $\mathrm{C} 100$ \\
\hline
\end{tabular}

Finally, the energy needs for the prototype accommodation needed to be satisfied by using seven photovoltaic panels of monocrystalline silicon with dimensions of $1.580 \times 808 \times 35 \mathrm{~mm}$ and a mass of $15.6 \mathrm{~kg}$. The size of the cells (individually) was $125 \times 125 \mathrm{~mm}$. As part of the charging system, a power inverter and a battery were integrated. The composition and integration of each one of the elements 
was essential for its proper function. Thus, the pieces of equipment needed to be synchronized with one another to obtain optimal results.

We depict below a schematic representation of supplying energy (as a function of the analyzed demand) to one lodging establishment in Cocachimba (Figure 8).

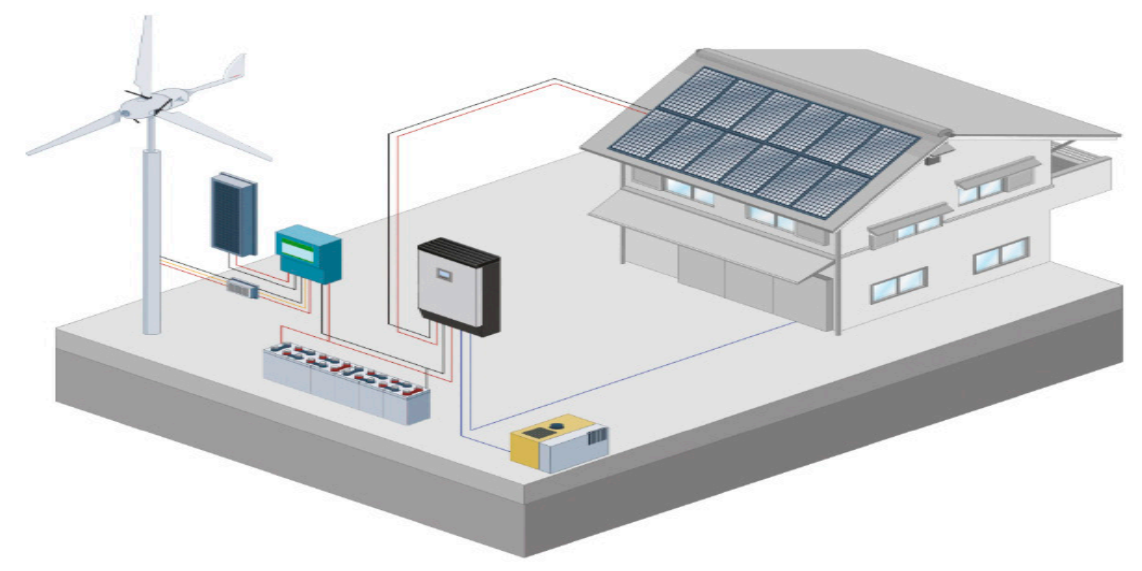

Figure 8. Schematic representation of self-sustaining establishment and the sources of electrical supply.

As one can notice in Figure 8, a hybrid supply, including solar and wind energy, was analyzed. It should be noted that the wind power improved significantly during January-March and December, although there was a better performance with solar energy. Nonetheless, a wind generator system should also be included to supply the main battery.

The supply of water heating and heating in the lodging establishment was also analyzed. Thus, using solar panels with an area of $5 \mathrm{~m}^{2}$ would represent $18 \%$ annual saved energy, with an annual supply of $30 \%$, hot water coverage and heating with $8 \%$ (by heated floor system).

Indeed, the use of these kinds of renewable resources certainly reduces $\mathrm{CO}_{2}$, emissions. This is shown in Figure 9, in which variables like solar radiation intensity and auxiliary sustainable sources (solar and hydraulic) achieve an annual reduction of $636 \mathrm{~kg}$ of $\mathrm{CO}_{2}$.

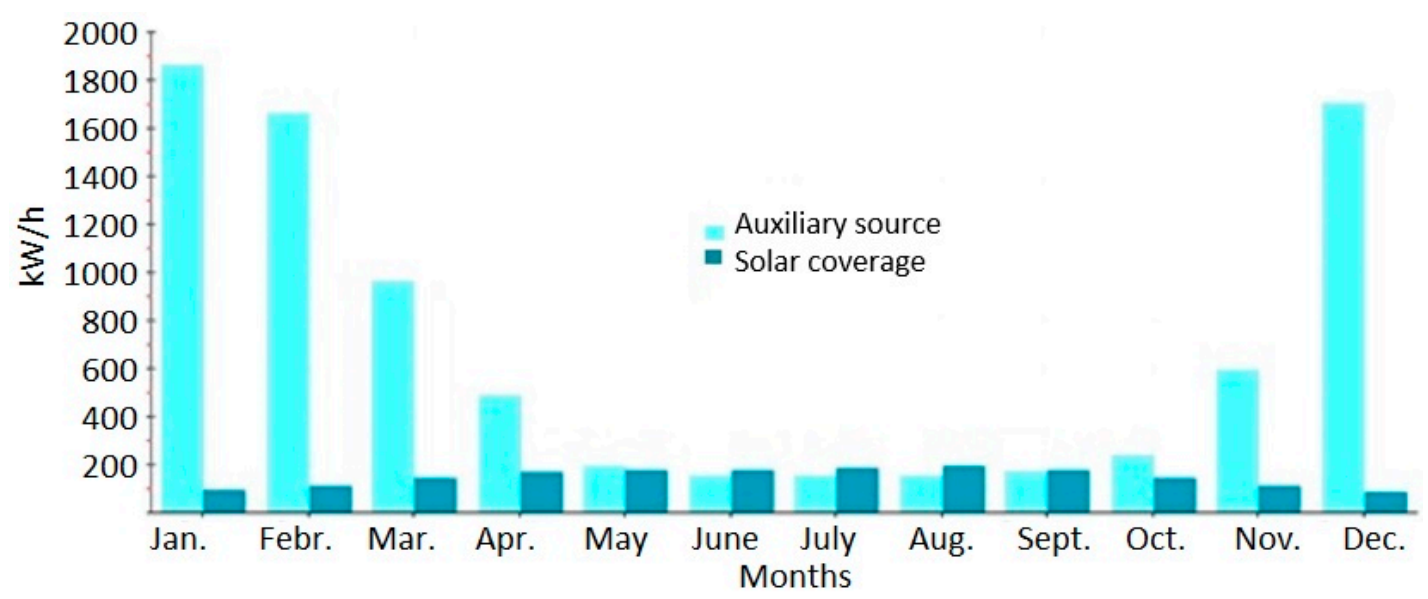

Figure 9. $\mathrm{CO}_{2}$ emissions reduction associated with the use of renewable sources during the months of a year.

For the study of the economic viability of the proposal, the use of the sensitivity analysis methodology was considered, formed by the costs that the installation of photovoltaic panels would demand according to the energy demand previously studied, as well as the weather conditions, the implementation of a solar heating system by Muro Trombe was considered. It should be noted that the results are linked to the study of a single house for conditioning purposes for its general replication. 
It should also be noted that the total costs will benefit a large percentage thanks to the new support policies implemented by the Peruvian government, aimed at the implementation of photovoltaic technology and the participation of non-governmental organizations in the implementation of solar heating systems, the latter for "Practical Solutions" [44].

The cost of the solar electrification system amounted to a total of US\$1034.00, while a solar heating system would be US\$320.00. According to the first, the Peruvian government, through agreements with international companies, would assume the total cost [43], with respect to the second, "Practical solutions" assumes $79.18 \%$, while families assume $20.81 \%$. Likewise, within the study a total of four tourists were considered to be hosted per house, with a cost of US $\$ 15.00$ per night, which, added to the service of guidance currently offered (US\$3.50 per tourist), constitutes the fixed monthly income. In this case, work was carried out according to a probabilistic pessimistic theme (a total of $50 \%$ of monthly nights with accommodation and guidance care). In addition to this, the inhabitants would also be required to make a symbolic payment that the Peruvian government for the use of solar electrification (US\$2.89 per month). Finally, an additional payment would be made for the conventional electrification service (because the solar system can only supply $46 \%$ of the total energy and thermal demand), with an average total of US $\$ 40.29$ monthly, and preventive evaluation-corrective US $\$ 29.85$ monthly, among others.

The results are optimistic, because with the proposed implementation there are gains. However, for a better understanding, an additional comparative study was carried out regarding the national minimum wage (NMW) in Peru, specifically for the year 2018 (with a US value of \$273.5), which showed the percentage change by positive and negative of the national minimum wage, until reaching a main objective, showing that the families dedicated to providing services to tourists surpassed $50 \%$ with respect to the national minimum wage. It is important to highlight that the national minimum wage in Peru has been growing on average $7.82 \%$ annually due to the great development in recent years, indirectly involving a better consolidation to local development projects within the national territory. The data related to the national minimum wage were considered from the year 2000 until the year 2018, where the last reform took place [36].

Figure 10 shows the feasibility with respect to the national minimum wage from the accommodation of two tourists, below that amount there is only a negative trend.

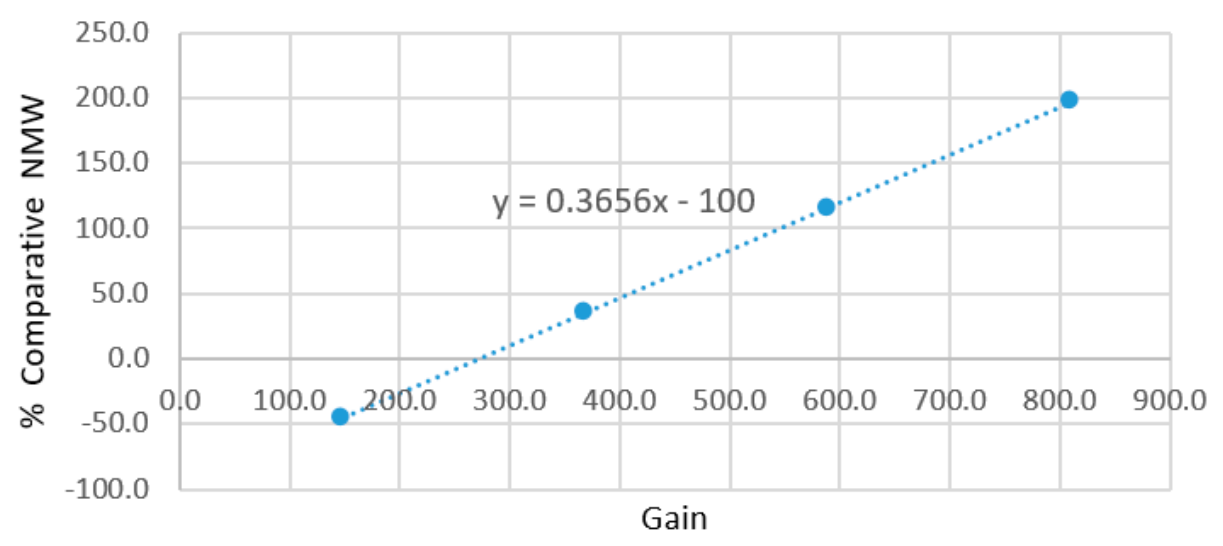

Figure 10. Variation in the gain in comparative function to the national minimum wage in Peru.

In 2017, the National Institute of Statistics and Informatics (INEI)-Peru established a methodology and levels of extreme poverty, non-extreme poverty, and the non-poor from a monetary index [45]. For this case, those who receive income according to the per capita monthly expenditure below US $\$ 55.00$ per person (average monthly cost of the family food basket) are within the group of extreme poor, in the range of US\$56.00-101.19 are non-extreme poor, and above the aforementioned range would be categorized as not poor. For this, Figure 11 analyzes the trend of the profit per person (considering five members for each family) based on the relative gain obtained by providing services 
for between one and four tourists per month (considering the pessimistic statistical case described in the analysis of sensitivity). It is evident that from two tourists one enters inside the projection of non-extreme poverty, with three tourists the ideal to be within a context of non-poverty.
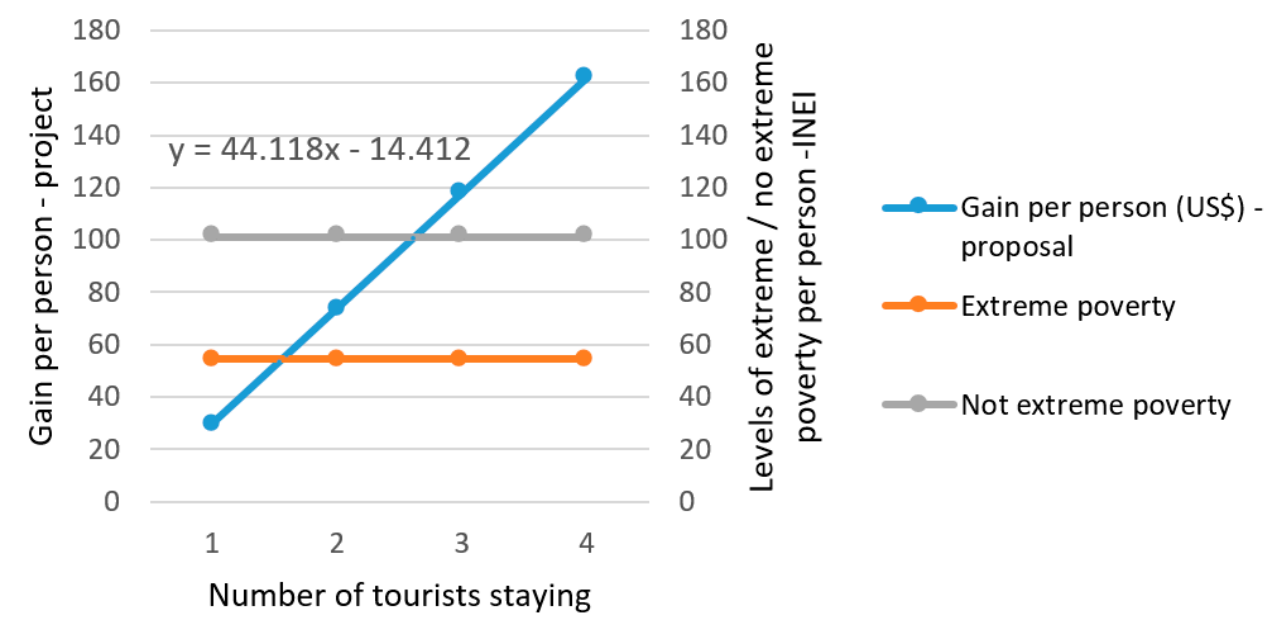

Figure 11. Representation of the profit per person based on the number of toursits hosted, and their comparative relationship with extreme and non-extreme poverty levels, according to data from INEI.

\section{Conclusions}

During the high season there is a deficit of accommodation establishments in Cocachimba. In those periods, $38.3 \%$ of visitors have no chance of finding a place to spend the night, which prevents them from taking advantage of the endogenous resources that the area has to create other tourist activities.

The results of the application of the TEFASAL multicriteria methodology advise opting for the habilitation of housing to cover the housing deficit, which are consistent with the natural context of the site and avoiding various forms of pollution, while implementing a reduction in fixed costs, promoting the use of renewable and clean energy. The proposed solution supposes, for each family that is associated with the process, a generation of income functioning as microenterprises, and achieving a local development based on the environmental, social, and economic factors, which involves local women.

By means of a quantified analysis of data from the geographic information system (GIS), we determined the average solar radiation intensity in Cocachimba to be $4.7 \mathrm{kWh} /$ day. Although the rate is low, it can be exploited by using solar systems with innovative designs. We have shown that the use of renewable resources has a major impact on the reduction in variable and fixed costs of the lodging establishments, as well as in the reduction of $\mathrm{CO}_{2}$, emissions, yielding a value of $636 \mathrm{~kg}$ annually.

Of the 50 families residing in the location, 30\% could benefit from the implementation of self-sustaining lodging establishments, which would increase the number of overnight stays of tourists. This opens new alternatives for touristic development in the location, extending the tourists' lengths of stay, and consequently, increasing the income of the locals. In addition, the self-sustaining establishments can effectively reduce variable and fixed costs related to energy supply, while an innovative proposal for building ecological houses can also be considered.

The sensitivity analysis indicates that to be profitable, it is necessary to provide the service to a minimum of two tourists, achieving a family gain equivalent to $34.9 \%$ above the national minimum wage (NMW) in Perú, with four being the maximum number of tourists per house, which means almost doubling the NMW. If we look the poverty levels estimated by the National Institute of Statistics and Informatics (INEI), two guests would be in the poverty range not extreme, with three the ideal number (not poverty). 
Author Contributions: Conceptualization, A.C.-G.; Data curation, F.C.-V. and A.C.-G.; Formal analysis, F.C.-V. and A.C.-G.; Investigation, D.A.-C. and F.C.-V.; Methodology, D.A.-C. and F.C.-V.; Project administration, D.A.-C.; Resources, D.A.-C.; Validation, F.C.-V., D.A.-C. and A.C.-G.; Writing-original draft, F.C.-V., D.A.-C. and A.C.-G.

Funding: This research received no external funding and The APC was funded by Universidad Privada del Norte-National Directorate of Research and Development, Perú.

Acknowledgments: The authors thank the National Direction of Research and Development from the Universidad Privada del Norte (DNID)-Perú. We are also particularly grateful to the anonymous referees for reading the article and giving their comments.

Conflicts of Interest: The authors declare no conflict of interest.

\section{References and Notes}

1. Carbajal, A. Manual Básico Para Agentes de Desarrollo Local y Otros Actores; Primera edición; eumed.net: Málaga, España, 2011.

2. PNUD. Informe Nacional De Desarrollo Humano. Available online: http://desarrollohumano.org.gt/ desarrollo-humano/concepto/ (accessed on 29 April 2017).

3. Vásquez Barquero, A. Desarrollo Endógeno, Teorías y Políticas De Desarrollo Territorial. Investig. Reg. 2007, 11, 183-210.

4. Shi, Y.; Du, Y.; Yang, G.; Tang, Y.; Fan, L.; Zhang, J.; Lu, Y.; Ge, Y.; Chang, J. The use of green waste from tourist attractions for renewable energy production: The potential and policy implications. Energy Policy 2013, 62, 410-418. [CrossRef]

5. Chaoqun, C. Researches on application of the renewable energy technologies in the development of low-carbon rural tourism. Energy Procedia 2011, 5, 1722-1726. [CrossRef]

6. Michalena, E.; Hills, J.; Amat, J. Developing sustainable tourism, using a multicriteria analysis on renewable energy in Mediterranean Islands. Energy Sustain. Dev. 2009, 13, 129-136. [CrossRef]

7. United Nations Development Programme [UNDP]. Trends in the Human Development Index 199-2014. 2015. Available online: http://hdr.undp.org/en/composite/trends (accessed on 9 August 2016).

8. Gössling, S.; Peeters, P. Assessing tourism's global environmental impact 1900-2050. J. Sustain. Tour. 2015, 23, 639-659. [CrossRef]

9. Bode, S.; Hapke, J.; Zisler, S. Need and options for a regenerative energy supply in holiday facilities. Tour. Manag. 2003, 24, 257-266. [CrossRef]

10. Hoogendoorn, G.; Fitchett, J.M. Tourism and climate change: A review of threats and adaptation strategies for Africa. Curr. Issues Tour. 2018, 21, 742-759. [CrossRef]

11. Katircioglu, S.T. International tourism, energy consumption, and environmental pollution: The case of Turkey. Renew. Sustain. Energy Rev. 2014, 36, 180-187. [CrossRef]

12. Munday, M.; Turner, K.; Jones, C. Accounting for the carbon associated with regional tourism consumption. Tour. Manag. 2013, 36, 35-44. [CrossRef]

13. Robaina-Alves, M.; Moutinho, V.; Costa, R. Change in energy-related $\mathrm{CO}_{2}$ (carbon dioxide) emissions in Portuguese tourism: A decomposition analysis from 2000 to 2008. J. Clean. Prod. 2016, 111, 520-528. [CrossRef]

14. Dogan, E.; Seker, F.; Bulbul, S. Investigating the impacts of energy consumption, real GDP, tourism and trade on $\mathrm{CO}_{2}$ emissions by accounting for cross-sectional dependence: A panel study of OECD countries. Curr. Issues Tour. 2015, 20, 1701-1719. [CrossRef]

15. Liu, J.; Feng, T.; Yang, X. The energy requirements and carbon dioxide emissions of tourism industry of Western China: A case of Chengdu city. Renew. Sustain. Energy Rev. 2011, 15, 2887-2894. [CrossRef]

16. Zhang, L.; Gao, J. Exploring the effects of international tourism on China's economic growth, energy consumption and environmental pollution: Evidence from a regional panel analysis. Renew. Sustain. Energy Rev. 2016, 53, 225-234. [CrossRef]

17. Gravouniotis, P.; Bauen, A.; Pearson, P. Building markets for energy saving equipment and modelling subsidy strategies in tourism dependent economies. Energy Procedia 2012, 18, 131-146. [CrossRef]

18. Irsag, B.; Puksec, T.; Duic, N. Long term energy demand projection and potential for energy savings of Croatian tourism-catering trade sector. Energy 2012, 48, 398-405. [CrossRef] 
19. Yang, G.; Li, P.; Zheng, B.; Zhang, Y. GHG Emission-Based Eco-Efficiency Study on Tourism Itinerary Products in Shangri-La, Yunnan Province, China. Curr. Issues Tour. 2008, 11, 604-622. [CrossRef]

20. Eneida, F.; Zayra, R. Innovative approaches for tourism's energy challenge. Responsible Tour. Ser. 2009, 147, 1-4.

21. OMT. Sustainable Development of Tourism. Available online: http://sdt.unwto.org/es/content/definicion (accessed on 10 May 2017).

22. Huanambal, V. Modelo del Complejo Científico, Ecológico y Académico. Santa María del Mar. M. Chong, Interviewer, 2011.

23. World Bank. Database Sustainable Energy for All; World Bank: Washington, DC, USA, 2015.

24. ONU Energía. PERÚ: Rapid Assessment and Gap Analysis. En Sustainable Energy for All Americas. 2014. Available online: https://www.seforall.org/sites/default/files/Suriname_RAGA_EN_Released.pdf (accessed on 4 September 2019).

25. Ley $N^{\circ}$ 24656. Diario Oficial El Peruano, Lima, Perú. 30 de Marzo del 1987.

26. Ministerio del Medio Ambiente. National Environment Policy; Legal deposit of the National Library of Peru $N^{\circ}$ 2010-16537; Editorial Supergráfica E.I.R.L: Lima, Perú, 2010.

27. Ley $N^{\circ}$ 29408. Diario Oficial El Peruano, Lima, Perú, 16 de Setiembre del 2009.

28. ONU. Report of the World Commission on Environment and Development. Future Brundtland Report. 1987. Available online: https:/www.are.admin.ch/are/en/home/sustainable-development/internationalcooperation/2030agenda/un-_-milestones-in-sustainable-development/1987--brundtland-report.html (accessed on 4 September 2019).

29. Roberto, G. Modernidad, medio ambiente y ética: Un nuevo paradigma de desarrollo. In Del Desarrollo Humano a la Economía Ecológica; En Crespo, C., y Ricaldi, T., Comps; CESU-UMSS/PNUD: Cochabamba, Bolivia, 1998; pp. 21-55.

30. United Nations Environment Programme and World Tourism Organization [UNWTO]. Tourism in the Green Economy-Background Report 2012. Available online: http://www.e-unwto.org/doi/book/10.18111/ 9789284414529 (accessed on 10 September 2016).

31. International Renewable Energy Agency [IRENA]. Renewable Energy Opportunities for Island Tourism. 2014. Available online: http://www.irena.org/DocumentDownloads/Publications/IRENA_RE_Island_Tourism_ report_2014.pdf (accessed on 17 June 2016).

32. MINCETUR-Ministerio de Comercio Exterior y Turismo. Memorial de Turismo Rural Comunitario en el Perú; Primera Edición; MINCETUR: Lima, Perú, 2015; pp. 18-23.

33. Asmat-Campos, D.; Carreño-Ortega, A. Recovering-innovation-exportation triangle as an instrument for sustainable development: Proposal for peruvian agro-export development. Sustainability 2019, 11, 1149. [CrossRef]

34. Contreras, E. Evaluación Social de Proyectos-Evaluación Multicriterio. CEPAL. 2009. Available online: https://www.cepal.org/ilpes/noticias/paginas/7/35117/ev_social_ILPES_2009_4_multicriterio.pdf (accessed on 7 August 2019).

35. Velez-Pareja, I. Sensitivity Analysis. 2007. Available online: https://ssrn.com/abstract=986887 or http: //dx.doi.org/10.2139/ssrn.986887 (accessed on 6 September 2019).

36. Instituto Nacional de Estadística e Informática [INEI]. Población al 2015. Available online: http://proyectos. inei.gob.pe/web/poblacion/ (accessed on 20 May 2017).

37. Diario Oficial El Peruano. Destacan Plan de Energías Renovables em Zonas Rurales. Diario Oficial. Available online: https:/elperuano.pe/noticia-destacan-plan-energias-renovables-zonas-rurales-81342.aspx (accessed on 11 July 2019).

38. El Heraldo. Resaltan Importancia de las Energías Renovables en el Perú. Agencia de Noticias del Congreso de la República del Perú. Available online: http://www2.congreso.gob.pe/Sicr/Prensa/heraldo.nsf/CNtitulares2/ 8e92e930d5ff82be05258076007b4bce/?OpenDocument (accessed on 21 July 2019).

39. Morante, F.; Zilles, R.; Espinoza, R.; Horn, M. Consumo de energía eléctrica en sistemas fotovoltaicos domiciliares de las comunidades de los Uros, Taquile, Amantaní y Huancho Lima de la región Puno, Perú. Energía Desarro. 2005, 26, 9-17.

40. Saaty, T. How to Make a Decision: The Analytic Hierarchy Process; University of Pittsburgh: Pittsburgh, PA, USA, 1994. 
41. Organismo Supervisor de la Inversión en Energía y Minería [OSINERGMIN]. Subasta de Suministro de Electricidad con Recursos Energéticos Renovables. Lima, Perú. 2019. Available online: http://www. osinergmin.gob.pe/empresas/energias-renovables/subastas (accessed on 1 July 2019).

42. Soluciones Prácticas. Muro Trombe (Calefacción Ecológica). Lima, Perú. 2015. Available online: https: //solucionespracticas.org.pe/ficha-tecnica-muro-trombe (accessed on 27 July 2019).

43. Comisión de Promoción del Perú para la Exportación y el Turismo [PROMPERÚ]. Perfil del Turista Extranjero. Turismo en Cifras. 2017. Available online: https://www.promperu.gob.pe/TurismoIN//Uploads/ temp/Uploads_perfiles_extranjeros_40_Book_PTE_2017_FINAL.pdf (accessed on 18 October 2018).

44. Banco Agrario [Agrobanco]. Créditos Para la Actividad Agropecuaria. Lima, Perú. 2019. Available online: https://www.agrobanco.com.pe/productos-y-servicios/ (accessed on 30 July 2019).

45. Instituto Nacional de Estadística e Informática [INEI]. Resultados de la Pobreza Monetaria 2017. Lima Perú. Available online: https://www.inei.gob.pe/media/cifras_de_pobreza/presentacion_evolucion-de-pobrezamonetaria-2017.pdf (accessed on 8 October 2018).

(C) 2019 by the authors. Licensee MDPI, Basel, Switzerland. This article is an open access article distributed under the terms and conditions of the Creative Commons Attribution (CC BY) license (http://creativecommons.org/licenses/by/4.0/). 